\title{
PERAN INVESTASI TERHADAP PERTUMBUHAN EKONOMI DI KABUPATEN JEPARA, TAHUN 2012-2016
}

Bono Prambudi

STIE Muhammadiyah Jakarta, bprambudi@yahoo.com

\begin{abstract}
Abstrak
Penelitian ini bertujuan untuk mengetahui hubungan dan pengaruh dari variabel independen terhadap variabel dependen yaitu investasi terhadap pertumbuhan ekonomi dari tahun 2012 hingga tahun 2016. Data yang digunakan dalam penelitian ini adalah data dari BPS (Badan Pusat Statistik). Dalam penelitian ini mengunakan analisis regresi liner sederhana. Hasilnya adalah investasi berhubungan positif dengan pertumbuhan ekonomi. Hal tersebut menunjukkan bahwa investasi merupakan faktor penting dalam mendorong pertumbuhan ekonomi di Kabupaten Jepara.
\end{abstract}

Kata Kunci : Investasi dan Pertumbuhan Ekonomi

\begin{abstract}
This study aims to determine the relationship and influence of the independent variables on the dependent variable, namely investment on economic growth from 2012 to 2016. The data used in this study are data from BPS (Statistics Indonesia). In this study using simple linear regression analysis. The result is that investment is positively related to economic growth. This shows that investment is an important factor in driving economic growth in Jepara Regency.

Keywords: Investment and Economic Growth
\end{abstract}

\section{PENDAHULUAN}

Pertumbuhan ekonomi merupakan bagian dari sebuah investasi dan pergerakannya merupakan yang positif, merupakan harapan yang diinginkan. Sehingga, pertumbuhan ekonomi merupakan perkembangan kegiatan dalam perekonomian yang menyebabkan barang dan jasa yang diproduksi dalam masyarakat bertambah, sehingga akan meningkatkan kemakmuran bagi masyarakat (Sukirno,1994 dalam Pambudi, 2013). Sedangkan menurut Lincolin (1997) dalam Pambudi (2013), mengartikan pertumbuhan ekonomi diartikan sebagai kenaikkan GDP/GNP tanpa memandang apakah kenaikan tersebut lebih besar atau lebih kecil dari tingkat pertumbuhan penduduk, dan apakah terjadi perubahan struktur ekonomi atau tidak. Sehingga dengan demikian, untuk menyambung benang merah tersebut, maka perekonomian yang paling ideal adalah ketika keadaan ekonomi suatu wilayah tumbuh secara kontinue tanpa mengalami penurunan atau perubahan yang menurun atau minimal grafik pertumbuhan mendatar. Namun pada kenyataannya, hal ini tidak mungkin terjadi, karena banyak faktor yang mempengaruhi pertumbuhan ekonomi suatu wilayah, mulai dari siklus perubahan investasi, hingga jumlah penduduk yang mempengaruhi input tenaga kerja. 


\section{JURNAL EKOBIS: EKONOMI, BISNIS \& MANAJEMEN}

\section{Volume 8 Nomor 2 (2018)}

Berkaitan dengan hal tersebut diatas, pertumbuhan ekonomi merupakan salah satu indikator yang umumnya dipergunakan untuk melihat kesuksesan keadaan perekonomian di suatu wilayah. Pertumbuhan ekonomi mengukur hasil dan perkembangan suatu perekonomian dari satu periode ke periode selanjutnya. Pertumbuhan ekonomi suatu wilayah dapat dilihat dari proses produksi barang dan jasa yang ada di wilayah tersebut. Produksi barang dan jasa itu dapat dilihat dari Produk Domestik Bruto (PDB). Produk Domestik Bruto atau PDB adalah nilai barang dan jasa yang dihasilkan dalam satu wilayah dalam satu tahun tertentu, dengan menggunakan faktorfaktor produksi yang di miliki penduduk yang berada di dalam wilayah tersebut (Sukirno, 2012:61 dalam Octavianingrum, 2015:18).

Maka dapat dijabarkan bahwa, kegiatan pembangunan ekonomi merupakan proses pertumbuhan ekonomi yang dilakukan oleh sebuah wilayah dan merupakan ukuran maju mundurnya keberhasilan pembangunan yang dilakukan oleh wilayah tersebut. Peningkatan dalam pertumbuhan ekonomi berarti terjadi kenaikan di dalam kegiatan atau aktivitas ekonomi di wilayah tersebut, jika terjadi penurunan maka kegiatan atau aktivitas di wilayah tersebut sedang mengalami penurunan ekonomi secara keseluruhan. Beragamnya permasalahan yang melingkupi relung-relung kegiatan ekonomi yang mewarnai pembangunan ekonomi bisa diselesaikan dengan solusi peningkatan jumlah modal dalam investasi. Salah satu bukti peran modal dalam investasi dalam pembangunan ekonomi terjadi di Kabupaten Jepara yang merupakan salah satu bagian dari Provinsi Jawa Tengah.

Kabupaten Jepara merupakan salah satu Kabupaten di Provinsi Jawa Tengah yang menghasilkan produk ukiran mebel yang sudah terkenal baik nasional maupun mancanegara. Banyak para wisatawan baik domestik maupun mancanegara yang mengunjungi kota Jepara pasti selalu membeli produk ukiran jati yang dihasilakan oleh penduduk kota ini. Berdasarkan prestasi yang sejak lama ditorehkan oleh kabupaten ini menarik minat para investor untuk menanamkan modalnya atau berinvestasi di Kabupaten Jepara untuk mengembangkan usaha mebel. Produksi mebel ukir sudah merambah hingga menjadi target pasar di mancanegara diantaranya adalah pasar Eropa, Amerika Serikat, Arab dan Asia. Peningkatan animo investasi yang datang banyak mengakibatkan dan mengeliatkan tumbuhnya show room-show room mebel baru yang khususnya ukir kayu jati di setiap desa- desa di Kabupaten Jepara yang otomatis meningkatkan sendi-sendi pertumbuhan ekonomi wilayah ini.

Tabel 1. PDRB Kabupaten Jepara Tahun 2012-2016

\begin{tabular}{|c|c|c|c|c|c|}
\hline \multirow{2}{*}{$\begin{array}{c}\text { Sektor } \\
\text { Lapang } \\
\text { an } \\
\text { Usaha }\end{array}$} & \multicolumn{5}{|c|}{$\begin{array}{c}\text { PDRB Kabupaten Jepara } \\
\text { (dalam Juta) }\end{array}$} \\
\hline & 2012 & 2013 & 2014 & 2015 & 2016 \\
\hline $\begin{array}{l}\text { Pengelo } \\
\text { laan } \\
\text { industri }\end{array}$ & $\begin{array}{c}4838 \\
349.62\end{array}$ & $\begin{array}{c}5148 \\
447.78\end{array}$ & $\begin{array}{c}5472 \\
144.33\end{array}$ & $\begin{array}{c}5756335 \\
.67\end{array}$ & $\begin{array}{c}601957 . \\
96\end{array}$ \\
\hline PDRB & $\begin{array}{c}1482499 \\
5.87\end{array}$ & $\begin{array}{c}1562373 \\
8.87\end{array}$ & $\begin{array}{c}1637471 \\
5.21\end{array}$ & $\begin{array}{c}1720036 \\
5.92\end{array}$ & $\begin{array}{c}1806313 \\
4.88\end{array}$ \\
\hline
\end{tabular}

Sumber : Data PDRB Atas Dasar Harga Konstan 2010-2017 


\section{JURNAL EKOBIS: EKONOMI, BISNIS \& MANAJEMEN}

Dari tabel tersebut mengenai hasil perhitungan PDRB tahun 2012 hingga 2016 dapat menjelaskan besarnya peran sektor industri pengolahan yang merupakan bagian dari PDRB Kabupaten Jepara mengalami peningkatan tiap tahun. Peningkatan industri pengolahan di dominasi dengan usaha mebel kayu ukir jati yang rata-rata peningkatannya sekitar 1,25\% hingga 2016 dari tahun 2012. Sedangkan perbandingan total PDRB dengan sektor industri mengalami peningkatan 3,2\% pertahun dari tahun 2012 hingga 2016 rata-ratanya pertahun, ini jika dilihat sepintas memang belum begitu banyak digali secara menyeluruh sektor ini. Namun diperlukan suatu kerja sama antar pihak yang berkepentingan dalam sektor industri pengolahan untuk menjadi andalan utama Kabupaten Jepara, karena kontri- businya cukup besar bila dibandingkan sektor lain. Dukungan dari Pemerintah Kabupaten sebagai pemangku kebijakan dalam kondisi peningkatanpembangunan di Kabupaten Jepara yang berlangsung secara keseluruhan dan berkesinambungantelah meningkatkan perekonomian secara bertahap. Pencapaian hasil- hasil pembangunan yang dirasakan masyarakat merupakan agregat dari desa-desa dan kecamatan yang ada dalam naungan wilayah Kabupaten Jepara tidak terlepas dari usaha semua unsur yang ada didalamnya yang berusaha memajukan Kabupaten Jepara. Namun disisi lain berbagai kendala dalam memaksimalkan potensi sumber daya, khususnya modal atau capital, dihadapi untuk memaksimalkan pengembangan atau pertumbuhan ekonomi baik dari tingkat terkecil dari desa hingga tingkat Kecamatan. Selama kurun waktu tahun 2012 hingga tahun 2017 tingkat pertumbuhan rata-rata menurut data BPS adalah sebesar $4,53 \%$ bila dibandingkan dengan tingkat pertumbuhan ekonomi Provinsi Jawa Tengah dari 35 Kabupaten/Kota berada diurutan 13 jauh dibawah kabupaten yang industrinya telah berkembang lebih dulu. Berdasarkan hal-hal ini yang telah disebutkan sebelumnya, maka dalam penelitian ini akan mengkaji tentang pertumbuhan ekonomi di Kabupaten Jepara dengan menggunakan variable investasi terhadap pertumbuhan ekonomi.

\section{KAJIAN LITERATUR}

\section{Investasi}

Investasi merupakan pengeluaran atau perbelanjaan penanaman-penanaman modal atau perusahaan untuk membeli barang dan jasa modal sebagai unsur pembentuk input dalam proses produksi dan perlengkapan-perlengkapan produksi untuk menambahkan kemampuan memproduksi barang-barang dan jasa-jasa yang tersedia di pasar. Investasi tujuanya tidak hanya untuk mengoptimalkan input untuk menjadi ouput yang maksimal, tetapi juga untuk menjaga siklus faktor-faktor produksi agar dapat di distribusikan dengan sesuai proporsinya dalam mendukung pembangunan dan meningkatkan kualitas dan kuantitas perekonomian disuatu wilayah secara keseluruhan (Fauzan, 2015:48).

Menurut Boediono (1992) dan Dornbusch \& Fischer dalam Rustiono (2008:41), investasi merupakan pengeluaran yang dilakukan oleh produsen untuk pembelian barang dan jasa untuk menambah stock investasi dan pendapatan dimasa mendatang demi menciptakan pendapatan lebih baik. Sejalan dengan pendapat Rustiono (2008:41), bahwa investasi sebagai pengeluaran- pengeluaran untuk membeli barang-barang modal dan peralatan-peralatan produksi dengan tujuan untuk mengganti dan terutama menambah barang- barang modal dalam perekonomian yang akan digunakan untuk memproduksi barang danjasa dimasa yang akan datang.

Ada empat faktor yang mempengaruhi investasi dalam pergerakan untuk menubuhkan ekonomi, antara lain;

1) Sumber daya manusia, merupakan faktor input yang sangat krusial dalam proses produksi 


\section{JURNAL EKOBIS: EKONOMI, BISNIS \& MANAJEMEN}

\section{Volume 8 Nomor 2 (2018)}

berkaitan dengan investasi yang dilakukan oleh investor. Sumber daya manusia baik dari sisi kuantitas tenaga kerja dan kualitas skill atau keahlian yang dimiliki. Para investor atau pelaku ekonomimeyakini bahwakualitastenaga kerja yang berupa keahlian, pengetahuan, dan disiplin sumber daya manusia merupakan unsur terpenting dalam pertumbuhan ekonomi, tanpa mengecilkan unsur pendukung input lain dalam proses produksi. Situasi efektif dan efisien dalam investasi baik barang dan jasa selalu dikaitkan dengan kualitas dan kuantitas sumber daya manusia yang direkut oleh investor. Peningkatan jumlah tersedianya sumber daya manusia bagi proses kegiatan produksi dapat terlihat baik dari jumlah tenaga kerja dalam arti orang ataupun dalam jumlah hari kerja orang (mandays) maupun jam kerja orang (manhours). Teori ekonomi telah menemukan bahwakemampuan seseorang untuk bekerja lebih banyak dipengaruhi oleh tingkat upah yang di sediakan oleh investor. Dengan kata lain, semakin tinggi tingkat upah, semakin tinggi kemampuan seseorang untuk men- ciptakan output dan akan berakibat kepada peningkatan kesejahteran secara pribadi. Hal ini akan meningkatkan pertumbuhan ekonomi secara umum di wilayah tersebut.

Teori ekonomi telah menemukan bahwa kemampuan seseorang untukbekerja lebih banyak

dipengaruhi oleh tingkat upah yang di sediakan oleh investor. Dengan kata lain, semakin tinggi tingkat upah, semakin tinggi kemampuan seseorang untuk men- ciptakan output dan akan berakibat kepada peningkatan kesejahteran secara pribadi. Hal ini akan meningkatkan pertumbuhan ekonomi secara umum di wilayah tersebut.

2) Sumber daya alam, termasuk dalam kategori

diantaranya adalah tanah, minyak, gas, hutan, air, serta bahan-bahan mineral. Beberapa negara telah mengalami pertumbuhan, terutama berdasarkan landasan sumberdaya yang sangat besar dengan output besar dalam bidang pertanian, perikanan, hutan dan migas. Namun, kepemilikan sumber daya alam bukan merupakan keharusan bagi keberhasilan ekonomi dunia modern. Negaranegara maju yang miskin akan sumber daya alam tetap dapat lebih maju dan secara ekonomi mengungguli negara berkembang lainnya, yang rata-rata memiliki hasil alam atau sumber daya alam melimpah. Hal ini dipengaruhi oleh adanya pemusatan perhatian pada sektor-sektor yang lebih tergantung pada tenagakerja dan kapital.

3) Pembentukan modal atau kapital, akumulasi kapital selalu menghendaki pengorbanan konsumsi pada saat ini selama beberapa tahun. Negara-negara yang tumbuh pesat cenderung berinvestasi sangat besar dalam modal baru. Pada negara-negara dengan pertumbuhan ekonomi yang paling pesat adalah sekitar $10 \mathrm{~s} / \mathrm{d} 20 \%$ output akan masuk dalam pertumbuhan modal bersih.

4) Perubahan Teknologi dan Inovasi, peningkatan kemajuan teknologi telah menjadi unsur vital keempat dari pertumbuhan standar hidup yang pesat. Dewasa ini, terjadi ledakan- ledakan teknologi baru, khususnya dalam informasi, komputerisasi, komunikasi, dan sains kehidupan. Perubahan teknologi menujukkan perubahan proses produksi atau pengenalan produksi dan jasa baru. Pentingnya peningkatan standar hidup membuat para investor atau ekonom sejak lama mempertimbangkan cara mendorong kemajuan teknologi. Semakin lama semakin jelas bahwa perubahan teknologi bukan hanya sekedar prosedur mekanisme untuk menemukan produk atau jasa dalam proses yang lebih baik. Sebaliknya, inovasi yang cepat memerlukan pemupukan semangat kewirausahaan (Samuelson, 2004:250 dalam Octavianingrum, 2015:29). 


\section{JURNAL EKOBIS: EKONOMI, BISNIS \& MANAJEMEN}

Sehingga dapat disimpulkan bahwa investasi merupakan bagian yang tidak dapat dipisahkan dalam proses pembentukkan pertumbuhan ekonomi dalam sebuah wilayah. Investasi tersebut tidak hanya belanja barang modal tetapi juga jasa modal, seperti tanah, bangunan, dan letak geografis atau sumber daya alam, sumber daya manusia, tata kelola manajemen, pendistribusian dan juga perubahan modal. Semakin besar investasi semakin tinggi tingkat pertumbuhan ekonomi wilayah tersebut, maka akan semakin maju dan berkembang wilayah tersebut dalam semua sektor sendi kehiduapannya.

\section{Pertumbuhan Ekonomi}

Pertumbuhan ekonomi merupakan perubahan struktur dalam proses pembangunan yang sudah lama muncul. Perubahan struktural ini biasanya ditandai dengan adanya perubahan pendapatan per-kapita yang diterima oleh masyarakat suatu negara atau dalam suatu wilayah. Masyarakat dalam suatu negara akan menerima pendapatan per-kapita yang lebih tinggi dibandingkan sebelum adanya perubahan struktural. Dengan semakin tingginya pendapatan per-kapita yang diterima oleh masyarakat suatu negara, maka akan menggeser peranan dari sektor lain yang kurang signifikan memberikan tambahan pendapatan, contohnya sektor pertanian ke sektor industri pengolahan dan jasa yang menjanjikan tingkat pendapatan yang lebih baik. Pergeseran sektor ini merupakan kewajaran yang normal dalam perubahan struktural ekonomi demi menciptakan sesuatu yang lebih baik dari sebelumnya (Suindyah D, 2009:4).

Pertumbuhan ekonomi merupakan proses dimana terjadi kenaikkan Produk Domestik Regional Bruto (PDRB) atau pendapatan Nasional riil. Jadi perekonomian dikatakan tumbuh atau berkembang bila terjadi pertumbuhan output riil (Wijaya, 2000 dalam Candra, 2012:4).

Menurut Teori Harrod Domar yang bertujuan menganalisis untuk menerangkan tentang pertumbuhan ekonomi dengan syarat yang harus dipenuhi supaya suatu prekonomian dapat mencapai pertumbuhan yang tumbuh atau steady state dalam jangka panjang, adalah sebagai berikut;

1) Barang modal telah mencapai kapasitas penuh (full employment).

2) Saving atau tabungan adalah proporsional terhadap pendapatan.

3) Rasio antara modal dan produksi (capital output ratio) adalah tetap.

4) Perekonomian adalah terdiri dari dua sektor (Putri, 2014).

Berdasarkan analisis yang dilakukan oleh Harrod dan Domar merupakan pelengkap dari analisis yang dilakukan oleh Keynesian. Dalam analisis yang dilakukan oleh Keynesian adalah persoalan ekonomi jangka pendek, sedangkan dalam analisis Harrod dan Domar merupakan analisis ekonomi jangka panjang. Dalam analisis Harrod dan Domar dapat di lihat bahwa;

1) Dalam jangka panjang pertambahan pengeluaran aggregate yang berkepanjangan perlu dicapai untuk mewujudkan pertumbuhan ekonomi.

2) Pertumbuhan ekonomi yang tumbuh hanya mungkin dicapai apabila $I+G(X-M)$ terus menerus bertambah dengan tingkat yang tinggi (Ayuningtyas,2012).

Sedangkan menurut teori pertumbuhan Neo Klasik, bahwa melihat persoalan pertumbuhan dari segi permintaan. Pertumbuhan ekonomi hanya berlaku apabila pengeluaran aggregate melalui kenaikan investasi bertambah terus-menurus pada tingkat pertumbuhan yang telah ditentukan 


\section{JURNAL EKOBIS: EKONOMI, BISNIS \& MANAJEMEN}

\section{Volume 8 Nomor 2 (2018)}

(Maharani dan Isnowati, 2014:64).

\section{METODE PENELITIAN}

Dalam penelitian ini data yang digunakan merupakan data sekunder yang seluruhnya berasal dari Badan Pusat Stastistik (BPS) periode 2012 hingga tahun 2017 (Hasan, dkk, 2015). Data diolah menggunakan tahap-tahap sebagai berikut:

a Metode Analisis

Untuk mengetahui pengaruh dari variabel bebas terhadap variabel terikat digunakan regresi liner sederhana. Regresi linear sederhana mempunyai ciri sebagai berikut; persamaan fungsi dan dapat diformulasikan kedalam bentuk persamaan matematika, nilai parameternya dapat ditentukan oleh a dan b yang dapat diukur dengan uji statistik melalui program SPSS dalam komputer. Setelah data diolah dan dianalisis secara kuantitatif untuk memberikan penjelasan/makna dari hasil kuantitatif.

Adapun formula dari model regresi linear tersebut adalah sebagai berikut:

$$
\mathbf{P E}=\mathbf{a}+\mathbf{b x}+\mathbf{e}
$$

Dimana $: \mathrm{PE}=$ Pertumbuhan Ekonomi $\mathrm{X}=$ Investasi

$$
\begin{array}{ll}
\mathrm{a} & =\text { Konstanta } \\
\mathrm{b} & =\text { Koefisien Regresi variable } \mathrm{x} \\
\mathrm{e} & =\text { Variabel lain yang tidakditeliti }
\end{array}
$$

\section{b. Interpretasi $\mathrm{R}^{2}$}

Keofisien determinasi $\left(\mathrm{R}^{2}\right)$ digunakan untuk mengetahui sampai sejauh mana ketetapan atau kecocokan garis regresi yang terbentuk dalam mewakili kelompok data hasil olahan dari observasi data. Jika nilai $\mathrm{R}^{2}$ mendekati 1 maka semakin baik. Koefisien determinasi $\left(\mathrm{R}^{2}\right)$ memperlihatkan besarnya pengaruh dari variabel independen terhadap variabel dependen (Maharani dan Isnowati, 2014).

\section{HASIL DAN PEMBAHASAN}

Berdasarkan Koefisien determinas $\left(\mathrm{R}^{2}\right)$ sebesar 0,741 berarti variabel investasi penanaman modal dalam bidang usaha industri pengolahan yang bergulir di Kabupaten Jepara mampu menjelaskan pertumbuhan ekonomi sebesar 74,1 persen dan sisanya dijelaskan oleh sektor lain diluar dari variabel yang diteliti dalam model. Jika dilihat dari probabilitas F-stastistik, sebesar 0,000 nilai ini lebih kecil jika dibandingkan dengan standar deviasi yang sebesar á $=5 \%$.

Hal ini menjelaskan bahwa variabel independen yakni variabel investasi berpengaruh terhadap variabel dependen yaitu variabel pertumbuhan ekonomi di Kabupaten Jepara. Hal ini menggambarkan bahwa Pemerintah Kabupaten Jepara jika ingin meningkatkan geliat ekonominya secara menyeluruh, harus dapat menggaet investor dari luar dan dalam, guna berusaha di sektor industri pengolahan khususnya dan umumnya sektor lain demi memajukan suasana ekonomi di wilayah Jepara. Aktivitas ini sesuai dengan visi dan misi Kabupaten yang berusaha menggeliatkan ekonomi masyarakatnya dengan mempermudah aturan-aturan pendirian usaha, pemberian bantuan pinjaman usaha kecil menengah dan hingga membuka sektor pendidikan yang bisa menciptakan 


\section{JURNAL EKOBIS: EKONOMI, BISNIS \& MANAJEMEN}

Volume 8 Nomor 2 (2018)

tenaga ahli madya yang siap guna di pasar.

Tabel 2. Model Summary

\begin{tabular}{|l|l|r|r|c|}
\hline Model & & & & \\
& $\mathrm{R}$ & $\mathrm{R}$ Square & Adjusted R Square & $\begin{array}{c}\text { Std. Error of the } \\
\text { Estimate }\end{array}$ \\
\hline 1 &, 741 &, 636 &, 639 &, 72004 \\
\hline
\end{tabular}

Tabel 3. ANOVAb

\begin{tabular}{|c|c|c|c|c|c|}
\hline Model & $\begin{array}{l}\text { Sum of } \\
\text { Squares }\end{array}$ & df & Mean Square & $\mathrm{F}$ & Sig. \\
\hline \begin{tabular}{|ll}
1 & $\begin{array}{l}\text { Regre } \\
\text { ssion }\end{array}$
\end{tabular} & ,204 & 1 & ,204 & 394 & ,000 \\
\hline $\begin{array}{l}\text { Resid } \\
\text { ual } \\
\text { Total }\end{array}$ & $\begin{array}{l}1,555 \\
1,760\end{array}$ & 3 & ,518 & & \\
\hline
\end{tabular}

Tabel 4. Coefficientsa

\begin{tabular}{|c|c|c|c|c|c|}
\hline \multirow[t]{2}{*}{ Model } & \multicolumn{2}{|c|}{$\begin{array}{l}\text { Unstandardized } \\
\text { Coefficients }\end{array}$} & \multirow{2}{*}{$\begin{array}{c}\text { Standardized } \\
\text { Coefficients } \\
\text { Beta } \\
\end{array}$} & \multirow[b]{2}{*}{$\mathrm{t}$} & \multirow[b]{2}{*}{ Sig } \\
\hline & B & $\begin{array}{l}\text { Std. } \\
\text { Error }\end{array}$ & & & \\
\hline $1 \quad$ (Constant) & 5,976 & ,603 & & 9,911 & $\overline{, 002}$ \\
\hline Investasi &, 000 &, 000 &,- 341 &,- 628 &, 000 \\
\hline
\end{tabular}

\section{PENUTUP}

Kesimpulan dari penelitian ini adalah bahwa investasi berhubungan positif dengan pertumbuhan ekonomi di Kabupaten Jepara. Hal tersebut berdasarkan hasil uji $\mathrm{R}^{2}$ dengan nilai 74,1 dengan uji $\mathrm{F}$ dengan probabilitas sebesar 0,000 . Ini menunjukan bahwa variabel independen berpengaruh secarasignifikan.

Berdasarkan pada hasil analisis di atas menunjukkan bahwa investasi sangatlah diperlukan untuk mendorong pertumbuhan ekonomi di Kabupaten Jepara, Jawa Tengah. 


\section{REFERENSI}

Ayuningtyas,Melina. 2012. Pengaruh Investasi, Pengeluaran Pemerintah dan Tenaga Kerja Terhadap Pertumbuhan Ekonomi Kabupaten/Kota Di Provinsi Jawa Tengah Tahun 2007-2009.Skripsi-UNES

Candra, Eddy Wibowo.2012.Analisis Peranan Pengeluaran Pemerintah, Tenaga Kerja Dan Penanaman Modal Dalam Negeri (PMDN) Terhadap Pertumbuhan Ekonomi Provinsi Jawa TimurTahun 2001-2010.Jurnal Ilmiah- UNIBRAW.

Fauzan, Alfian Wahyu.2015.Analisis Pengaruh Investasi, Tenaga Kerja, Dan Tingkat Pendidikan Terhadap Pertumbuhan Ekononomi (Studi Kasus: Kabupaten/Kota di Provinsi Jawa Tengah Tahun 2009-2013). Skripsi-UNDIP Semarang.

Has an, Efrizal., A mar, Sy a msul., d an Anis, Ali. 2015. Pengaruh Investasi, Angkatan Kerja, dan Pengeluaran Pemerintah Terhadap Pertumbuhan Ekonomi di Provinsi Sumatra Barat.Artikel Ekonomi.Hal:1-13.

Maharani,Kurnia.,dan Isnowati,Sri. 2014. Kajian Investasi, Pengeluaran Pemerintah, Tenaga Kerja, dan Keterbukaan Ekonomi Terhadap Pertumbuhan Ekonomi Di Provinsi Jawa Tengah. Jurnal Bisnis dan Ekonomi (JBE).Vol.21(1).Hal:62-72.

Octavianingrum, Denty. 2015. Analisis Pengaruh Investasi, Tenaga Kerja, dan Tingkat Pendidikan Terhadap Pertumbuhan Ekonomi Di Daerah Istimewa Yogyakarta: Studi 5 Kabupaten/Kota.Skripsi-UNY.

Pambudi, Miyasto Eko Wicaksono.2013.Analisis Pertumbuhan Ekonomi Dan Faktor-Faktor Yang Mempengaruhi Studi Kasus kabupaten/Kota Di Provinsi Jawa Tengah. Jurnal Ekonomi UNDIP. Vol.2(2). Hal.1-11.

Putri, Phany Ineke.2014.Pengaruh Investasi, Tenaga Kerja, Belanja Modal, dan Infrastrktur Terhadap Pertumbuhan Ekonomi Pulau Jawa.Journal of Economics and Policy (JEJAK).Vol.7(2):100-202.

Rustiono,Deddy. 2008. Analisis Pengaruh Investasi, Tenaga Kerja, dan Pengeluaran Pemerintah Terhadap Pertumbuhan Ekonomi DiProvinsi Jawa Tengah.Tesis-UNDIP.

Suindyah D.Sayekti. 2009. Pengaruh Investasi, Tenaga Kerja, dan Pengeluaran Pemerintah Terhadap Pertumbuhan Ekonomi Di Provinsi Jawa Timur. Jurnal Ekuitas. Vol.15(4):477500 . 